\title{
Anvendt etik og forhandlet normdannelse
}

\author{
Thomas Achen
}

Anvendt etik har i for ringe grad interesseret sig for de procedurale og refleksive aspekter ved det som $i$ artiklen kaldes den forhandlede normdannelse. Diskursetikken således som den udvikles hos Jürgen Habermas kan fungere som teoretisk ramme for en sådan analyse. Artiklen prosenterer en undersøgelse af det svenske Gentekniknovn med henblik på at vise hvorledes den forhandlede normdannelse foregår i dette novn. Artiklen konkluderer på baggrund heraf at den forhandlede normdannelse peger på et bredere politisk spørgsmål om mulighedsbetingelserne for et deliberativt demokrati. I denne optik er anvendt etik ikke primart et spørgsmål om applicering af normer eller principper, men om studiet af mulighedsbetingelserne og formerne for en kollektiv evaluering af det normative grundlag for konkrete handlinger. ${ }^{1}$

Nøgleord: forhandlet normdannelse, diskursetik, anvendt etik, Gentekniknævnet, proceduralisme.

\section{Refleksivitet, proceduralisme og anvendt etik}

Hvordan skal vi forstå det forhold at de normer som styrer udviklingen og anvendelsen af genteknik i fødevareproduktionen, i høj grad sker i specialiserede og ofte partssammansatte råd og nævn? I denne artikel skal jeg med udgangspunkt $i$ en emperisk analyse af det svenske Gentekniknævn argumentere for at der er tale om en forhandlet normdannelse. Begrebet om den forhandlede normdannelse bygger på en antagelse om at normdannelse i det (post)moderne samfund sker under trykket fra en radikaliseret begrundelsestvang. At kunne analysere og reflektere disse forhold er en afgørende udfordring for den anvendte etik.

Debatten om det moderne og det postmoderne optog en væsentlig del af den intelektuelle opmærksomhed fra slutningen af 1970’erne og skær- 
pede opmærksomheden omkring det forhold at de store fortællinger om ideologi, moral og religion er sat under debat, og ikke længere kan gøre krav på nogen privilegeret position hvorfra sandhedspåstande kan formuleres ${ }^{2}$. Ideologiernes, moralens og religionernes store fortællinger mødes med en skepsis mod hele den oplysningsfilosofiske balast som de gennemsyres af. Den postmoderne kritik retter sig mod oplysningsmodernismens syntetiserende ambition, og stiller sig kritisk til centrale begreber som f.eks. subjektbegrebet, intentionalitetsbegrebet og rationalitetsbegrebet (Schanz 1988: 43-45). Denne debat spredte en produktiv skepsis i store dele af human- og samfundsvidenskaberne som åbnede op for undersøgelser af institutioner og politiske processer hvor rationalitet og intentionalitet ikke forudsættes, men er en del af undersøgelsernes genstandsfelt.

Den rationalitets- og intentionalitetskritik som vokser frem i debatten, får i samfundsvidenskaberne en konkret udløber fra slutningen af 1980’erne og op gennem 1990'erne hvor vi ser fremvæksten af en forskning som intresserer sig for en ny samfundsmæssig refleksivitet som kan identificeres i institutioner, lovgivninger og politiske processer. Forfattere som bl.a. A. Giddens, U. Beck, M. Hajer, P. Nonet \& P. Selznick og G. Teubner kan ses som eksponenter for denne forskning. I lighed med den postmoderne kritik fra 1980'erne peger disse forfattere på at politisk og social normdannelse skabes under betingelser som fordrer en ny form for refleksivitet og responsivitet for at sikre den normative gyldighed i de politiske, juridiske og sociale systemer. Der opstår således et behov for en ny refleksiv kompetence i samfundets institutioner (Luhmann 1992: 16-20; Pedersen et al 1992: 117-159; Stehr 2003: 145-155). Et eksempel på hvorledes denne refleksivitet udmyntes, ser vi i de institutioner som er blevet skabt de sidste 15-20 år for at varetage centrale dele af den normative styring af f.eks. anvendelsen af genteknik i fødevareproduktionen. Det svenske Gentekniknævn som jeg skal diskutere i denne artikel, er et eksempel på en sådan institution.

En institution som Gentekniknævnet står over for en styrings- og reguleringsopgave, hvor det på den ene side kræves at den leverer et konsistent normativt grundlag for politikken på fødevareområdet, og på den anden siden er produktionsbetingelserne for tilvejebringelsen af dette normative grundlag underlagt de refleksivitets- og gyldighedsproblemer som præger det senmoderne samfund. For en normproducerende (normerende) institution som Gentekniknævnet kan der i dag ikke være tale om at henvise til allerede etablerede etiske teorier, for derigennem at motivere en vis handling. I stedet må institutioner som Gentekniknævnet besinde sig på den forhandlede normdannelse som udgør den procedurale ramme for normproduktionen. Man kan vende argumentet om og i stedet sige, at hvis en institution som Gentekniknævnet ikke formår at skabe en normdannelsesproces som tillader en forhandling om det normative indhold i de handlingsnomer som foreslås i forbindelse med behandlingen af et konkret spørgsmål, så forsvin- 
der forudsætningerne for at de normer som bliver resultatet af en given normdannelsesproces, besidder den gyldighed som er nødvendig for at normerne skal opleves som forpligtende.

Når jeg således betoner proceduralismen, og i forlængelse heraf en proceduralistisk etik, hænger det sammen med behovet for at forstå vilkårene for den samfundsmoessige produktion af normativ gyldighed. En sådan etisk bestræbelse er afgørende hvis den anvendte etik skal kunne bidrage til at øge vores forståelse af normproduktion og normativ styring, uden for de medicinske og kliniske sammanhænge hvorfra den anvendte etik har udviklet sig (Winkler 1993: 343ff.). En procedural etik er ikke en etik der sværger sig fri fra en egen normativitet. Tværtimod bygger den proceduralistiske etik på den forudsætning, at hvad vi bør søge efter er en etik som med Matthias Kettners ord:

[...] imposes a number of morally relevant constraints on the rational acceptability of any proposed or already entrenched substantive moral principles, concrete norms of action, value-orientations etc. (Kettner 1993: 33)

Jeg skal udvikle denne idé yderligere ved at diskutere diskursetikken således som den formuleres hos Jürgen Habermas (Habermas 1990). Jeg vil hævde at diskursetikken tilfører den anvendte etik et helt nødvendigt perspektiv som gør den anvendte etik i stand til at nærme sig den institutionelle og politiske normdannelse. Ved at bringe den anvendte etik i forbindelse med diskursetikken kan den anvendte etik udvikles på to centrale områder:

- For det første kan den bibringes en teoretisk model for normativ evaluering i det Habermas kalder praktiske diskurser.

- For det andet kan den anvendte etik indlejres i en teori om etikkens politiske og institutionelle mulighedsbetingelser under (post)moderne vilkår.

Behovet for at skabe gyldighed via en normativ begrundelsesprocedure peger på at der i en vis forstand er tale om en moralisering af den samfundsmæssige kontekst som omgiver normproduktionen. Moraliseringen hænger sammen med at den nævnte begrundelsestvang, på en måde vi ikke tidligere har set, bevirker at normative konflikter løftes op til overfladen af det offentlige liv. En sådan eksponering løser imidlertid ikke i sig selv de normative problemer, men opmærksomheden omkring problemernes tilstedeværelse som en samfundsmæssig realitet øges. Debatten om genetisk modificerede fødevarer, samt debatten om det klonede får Dolly, er blot to eksempler på de bioetiske problemstillinger som med fordel lader sig forstå inden for rammerne af moraliseringstesen og den dermed forbundne tese om begrundelsestvangen. Moraliseringen betyder endvidere at de etiske problemer formuleres, projiceres og fokuseres via de politiske og retslige institutioner, etiske komitéer etc. som man har bygget op for at håndtere 
bioetiske konflikter. Man kan således med en vis ret hævde at moraliseringen af samfundet reflekteres af en politisering og institutionalisering af de forhold hvorunder moralske normer produceres. Disse samfundsmæssige forskydninger indebærer at de bioetiske spørgsmåls løsning forudsætter at de bearbejdes i institutionaliserede gyldighedsproducerende begrundelsesprocedurer. Arbejdet i Gentekniknævnet kan ses som et specifikt eksempel på netop en sådan bearbejdning (Achen 1997: 275-276).

Den situation som udspiller sig i en praktisk diskurs, er en situation, hvor mennesker gennem en kommunikativ interaktion forsøger at opnå konsensus om det normative grundlag for at handle med henblik på at løse et givet problem. Habermas formulerer denne grundtanke således:

[Discourse ethics] provides no substantive guidelines but only a procedure: practical discourse. Practical discourse is not a procedure for generating justified norm but a procedure for testing the validity of norms that are being proposed and hypothetically considered for adoption. That means that practical discourses depend on content brought to them from outside (Habermas 1990: 103)

Det er en central pointe for Habermas at den praktiske diskurs forlener de normer som bliver resultatet af den normative evaluering i den praktiske diskurs, med normativ gyldighed gennem en kollektiv handlingskoordinering; altså at deltagerne handler på baggrund af en evaluering af de muligheder og konsekvenser som forskellige handlingsnormer tilbyder. Den kollektive normdannelse viser sig også ved at de spørgsmål som overhovedet kan behandles i en praktisk diskurs, er sådanne spørgsmål som drejer sig om hvad der er godt for alle med hensyn til f.eks. fordeling af ressourcer eller distribution af politisk magt. Forskydningen fra den traditionelle etiks individorienterede perspektiv til diskursetikkens kollektivistiske perspektiv indebærer at diskursetikkens overordnede evalueringsprincip er spørgsmålet om retfoerdighed.

I januar 2007 publicerede EU-kommissionens generaldirektorat for forskning, videnskab, økonomi og samfund en rapport, som i lighed med mit argument i denne artikel hævder at de udfordringer som f.eks. genteknologien stiller samfundet overfor, ikke kan løses inden for rammerne af en traditionel etisk teori som opfatter ansvar som et resultat af individuelle handlinger ${ }^{3}$. Når det drejer sig om store tekniske systemer som f.eks. genteknologi behøver vi en etik som kan forstå ansvar $i$ relation til kollektive beslutninger (von Schomberg 2007: 5). Det bliver i forlængelse heraf samfundets omgang med viden som formuleres som det centrale etiske problem. Rapporten foreslår at en moderne vidensetik fokuserer på de mekanismer og processer som mobiliseres når viden overføres mellem forskellige samfundsmæssige sfærer, som f.eks. mellem videnskab og politik. En sådan etik må reflektere det forhold at når viden transformeres fra et system til et andet, så overskrides også systemspecifikke normative grænser. Sådanne 
normative grænser består ikke udelukkende af antagelser eller holdninger som der for øjeblikket råder konsensus om. Tværtimod er der ofte tale om normative grænser som består af relativt stabile normer og principper, nedfældet i lovgivninger eller i fundamentale politiske beslutninger (von Schomberg, 2007: 16). Den forhandlede normdannelse man ser i Gentekniknævnet, er netop et udtryk for en forhandling der balancerer mellem en forhandling om tilvejebringelse af en øjeblikkelig konsensus omkring akutte handlingsnormer, og en refleksiv bearbejdning af mere stabile retslige og/eller politiske normsystemer. Denne normative bearbejdning af mere eller mindre stabile normer er i sig selv normerende for de myndigheder og organisationer som findes i Gentekniknævnets omverden.

\section{Forhandlet normdannelse i Gentekniknævnet}

Gentekniknævnets arbejde reguleres i en instruktion fra $1994 .{ }^{4}$ Ifølge instruktionen skal Gentekniknævnet beskæftige sig med følgende spørgsmål:

- Sikre en etisk forsvarlig anvendelse af genteknik.

- Ytre sig i alle godkendelsessager vedrørende introduktion af GMO-produkter på markedet eller udslip i miljøet.

- Samråde med andre myndigheder i alle sager der er relevante for nævnets resortområde.

- Holde sig orienteret om projekter som har en sådan karakter at særlige etiske overvejelser må inddrages.

- Foreslå særlige forsigtighedsregler hvis et projekt gør det påkrævet.

- Følge den generelle udvikling på det genteknologiske område.

- Informere offentligheden på en sådan måde at interessen for etiske spørgsmål og sikkerhed opretholdes og den offentlige debat stimuleres.

Instruktionen slår også fast at Gentekniknævnet består af en formand og en næstformand samt 14 medlemmer. Formanden og næstformanden skal være jurister med dommererfaring. 7 af de 14 medlemmer skal være medlemmer af Riksdagen og et medlem skal være etisk sagkyndig. De øvrige medlemmer udses efter indstilling fra Stiftelsen för miljöstrategisk forskning (FORMAS) (2 medlemmer) samt fra Vetenskapsrådet (VR) (4 medlemmer) (Achen 2005: 33-36).

Gentekniknævnet er tydeligt opdelt i politikere, eksperter, etikere og jurister. Jeg skal nu gå over til en diskussion af de forskellige videnssystemer som findes repræsenteret i Gentekniknævnet og hvorledes representanterne i nævnet ser på deres egen og andres rolle i den forhandlede normdannelse i Gentekniknævnet. Diskussionen bygger på et studie om Gentek- 
niknævnet jeg lavede i 2003-2004. Studiet inkluderede en fuldstændig gennemgang af nævnets arkiv samt interviewer med alle nævnets daværende medlemmer (Achen 2005).

\section{Politik}

En af de politiske repræsentanter i nævnet peger på at diskussionen i nævnet primært udspiller sig mellem de politiske repræsentanter og forskerrepræsentanterne. Den etiske ekspertise får i relation hertil rollen som formidlere mellem de politiske og de naturvidenskabelige synspunkter (Interview, politiker II, okt. 2003). Men etikken kommer, ifølge en af nævnets politiske repræsentanter, ikke udelukkende fra den etiske sagkundskap. De etiske perspektiver føres desuden ind i diskussionen via de politiske synspunkter. Ifølge denne politiker er politikken impregneret med en normativitet som stammer fra det grundliggende natur- og menneskesyn, som de forskellige politiske traditioner og ideologier fører med sig. Det er interessant at bemærke, at politikken her ses som værende i besiddelse af en specifik etisk kvalitet, som er uafhængig af den etik, som formuleres og formidles ud fra den etiske sagkundskabs moralfilosofiske udgangspunkt. Set fra denne synsvinkel flyder etikken ind i Gentekniknævnet fra to kilder: De politiske idétraditioner og moralfilosofien.

En væsentligt mere kritisk analyse møder vi hos en repræsentant, som peger på at balancen i nævnet mellem politikken, videnskaben, etikken og juraen ikke altid opretholdes på en tilfredsstillende måde. Denne repræsentant understreger at det politikerne i Gentekniknævnet primært kan og skal bidrage med, er at vække opinion. Dette skal ske ved:

[...] att skapa arenor för debatt, att sprida kunskap, för mig borde det vara den överskuggande uppgiften [...] (Interview, politiker III, okt. 2003)

Opinionsdannelse er således en specifik politisk opgave, som risikerer at nedtones når og hvis politikken stiller sig i videnskabens, juraens eller etikkens tjeneste. Samme politiske repræsentant mener at Gentekniknævnet burde udvikle:

[...] mera offensiva grepp och grepp som öppnar ögonen på människor som aldrig någonsin skulle gå in på gentekniknämndens hemsida [...] jag skulle önska mig att nämnden var mera offensiv och mindre konventionell (Interview, politiker III, okt. 2003)

Ønsket om at nævnet skulle være mere offensivt og mindre konventionelt forudsætter, ifølge denne politiker, en øget politisk, juridisk og etisk profilering af nævnet. Samme politiske medlem mener videre, at en af grundene til at denne profilering ikke har været mulig i Sverige er, at: «Dom naturve- 
tenskapliga angreppssätten är helt dominerande [...]» (Interview, politiker III, okt. 2003). Det er et stort problem for denne politiker, at den etiske modvægt til den naturvidenskabelige dominans i nævnet ikke er tilstrækkelig stor. Det som denne politiker savner er en tydligere fokusering på spørgsmålet om, hvilke metaetiske analyseværktøjer som tilbyder sig for nævnet i denne eller hin konkrete situation. En sådan metaetisk analyse kan anvendes for at formulere nødvendige opinionsmobiliserende normative udsagn vedrørende bioteknikken (Interview, politiker III, okt. 2003).

At skabe opinion er også et vigtigt tema for en anden af de politiske repræsentanter i Gentekniknævnet. Men problemet angribes fra en lidt anden vinkel. Denne politiker understreger indledningsvis, at der findes en stor gensidig respekt i nævnet for de forskellige medlemmers specialområder. Her peges der specifikt på den juridiske kundskab i nævnet, som et godt eksempel på denne respekt. I forhold til politikerne i nævnet udmærker juristerne sig, ifølge denne politiker, ved ikke at forsøge at træde ind på det politiske område (Interview, politiker IV, okt. 2003). Når det gælder spørgsmålet om, hvorvidt Gentekniknævnet er tilstrækkeligt proaktivt, siger denne politiker:

Det skulle vara mycket roligare om man var liksom mera aktiv att allmänheten känner till att den här nämnden det är en klok nämnd [...] skall man vara aktiv på det sättet och slå sig igenom bruset [...] då räcker det ju inte bara att ha den kompetens som finns i gruppen då måste man ju också ha massmediakompetens eller attnå-ut-kompetens. (Interview, politiker IV, okt. 2003)

En mediekompetence i nævnet skulle således kunne hjælpe til med formidlingen af de problemstillinger som nævnet arbejder med til en bredere almenhed. At være proaktiv tolkes således som et spørgsmål om at få offentligheden i tale.

For andre af de politiske repræsentanter er hovedspørgsmålet snarere, hvem der egentlig besidder magten til at formulere den biopolitiske dagsorden i Gentekniknævnet. En af de politiske repræsentanter betoner, at samarbejdet mellem den politiske, naturvidenskabelige, etiske og juridiske kompetence i nævnet fungerer godt. I særdeleshed betones relationen mellem politikerne og de etiske/samfundsvidenskabelige sagkyndige i nævnet. Det samarbejde, som findes mellem disse to grupper i nævnet, kan i visse tilfælde trække en beslutning i en vis retning, alene ud fra en analyse af, hvad der opfattes som etisk forsvarligt og samtidig som politisk muligt. Således peger denne politiker på, at politikken og etikken i mange tilfælde kan have en slags fortrin i forhold til de videnskabelige analyser. I forlængelse siges det om den politiske sagkundskab, at der findes en:

[...] stark konstellation av sakkunskap inom många områden och där politiken ju också är en sakkunskap, det finns ju ändå en känsla av att, jaha, det här har ni kanske rätt i men det är faktisk politisk omöjligt (Interview, politiker V, okt. 2003) 
Den stærke konstellation af politisk og samfundsvidenskabelig/etisk ekspertise anser denne politiker for at være vigtig, da den bl.a. sikrer at en vis type af politisk-normative spørgsmål stilles.

Når det drejer sig om det interne samarbejde og om politikernes og politikkens stilling i forhold til de andre vidensformer, som er repræsenteret $\mathrm{i}$ nævnet, så nævner en af de politiske repræsentanter, at de naturvidenskabelige repræsentanter har et forspring, når det drejer sig om at forstå selve substansen i de spørgsmål Gentekniknævnet behandler. I den forbindelse siges det at:

[...] det som jag kanske kan vara lite kritisk till är hur man väljer dom politiker som skall vara med, det får ju inte vara så att politikerna också har en kunskapsbank med sig, så att säga, som är lite grann åt det här hållet (naturvidenskab, TA) utan jag tycker att politikerna skall ju vara dom förtroendevalda som skall prata mera allmänt utifrån hur folk...och bedöma den biten, och kunna möta forskarna och ställa relevanta frågor, kritisk granskande [...] När jag fick förfrågan att sitta i den här gentekniknämnden var min första reaktion, oj, klarar jag av det? Men då sa man just det, vi skall inte ha några experter ifrån politikerhåll för det finns det redan [...] jag upplever mig själv då som en utav dom här som inte är så kunniga i dom här frågorna, men som också bär på den här oron, var tar vi vägen liksom [...] (Interview, politiker VI, okt. 2003)

Det argument som toner frem her, kan beskrives som en variant af et klassisk modkvalificeringsargument. Denne politiker betoner, for det første, problemet med hensyn til at politikerne i nævnet, samtidig med at de repræsenterer offentligheden, også indtager en rolle som eksperter. For det andet identificerer denne politiker sig selv med rollen som repræsentant for en urolig offentlighed. Det er en privilegeret rolle i den forstand, at den berettiger og opmuntrer til at rejse de nødvendige kritiske spørgsmål til de videnskabelige, etiske og juridiske eksperter i nævnet. Således bliver den almindelige borgers perspektiv, som denne politiker identificerer sig med, en modkvalifikation i sin egenskab af at være (eller tolkes som) en autentisk røst som udspringer fra de lag i samfundet hvor uroen og usikkerheden om genteknikkens konsekvenser findes. Men denne politiske repræsentants udtalelse kritiserer også sammenblandingen af rollen som politiker og ekspert.

Blandt Gentekniknævnets politiske repræsentanter findes der dem, som mener, at Gentekniknævnet er en arena for en ideologisk kamp mellem tilhængere og modstandere af en innovativ teknologipolitik og en økonomisk politik med sigtet instillet på vækst.

En politiker i nævnet deklarerer tydligt, at den dominerende normative og ideologiske konfliktlinje i nævnet løber internt blandt de politiske repræsentanter. Denne analyse uddybes således: 
[...] det är den klassiska teknikpositiva tillväxtsidan Socialdemokratin, Moderaterna, Folkpartiet på ena sidan och dom rabiata nej-förespråkarna med Miljöpartiet och Kristdemokraterna å ena sidan och sen Centern och Vänsterpartiet som ofta hamnar där, men som ibland är mera på den andra sidan, så det är inte den klassiska block grejen, utan det är snarare så att det är tillväxtivrare jämfört med dom som är nej till kärnkraft, nej till bioteknik nej till [...] ja, vad jag brukar kalla allt som är framåtsträvande (Interview, politiker VII, nov. 2003)

Den konfliktlinie, som trækkes op her, sprænger delvist de traditionelle politiske blokgrænser. Men det er samtidig en polemisk opdeling som denne repræsentant foretager, idet de partier som er skeptiske i forhold til genteknikken, også antages at være modstandere af fremskridt og vækst i det hele taget. Denne udtalelse er interessant, fordi den viser et næsten arketypisk eksempel på, hvorledes genteknikken i en vis politisk optik forlenes med fremtidsoptimisme og en garanti for at Sverige skal kunne indtage sin (ledende) plads i videnssamfundet. Derimod opfatter denne politiker relationen mellem de politiske repræsentanter og de sagkyndige som uproblematisk. Den politiske repræsentant siger konkluderande om dette spørgsmål:

Alla experterna (både de naturvidenskabelige og de etisk-samfundsvidenskabelige, TA) dom bidrar med mera objektiv sakkunskap och sen så kommer då de politiska avvägningarna (Interview, politiker VII, nov. 2003)

De politiske afvejninger foretages, ifølge dette medlem, efter at politikerne er blevet informeret af en objektiv ekspertise. Det er intressant at notere, at også den etiske og samfundsvidenskabelige sagkundskab siges at kunne levere objektiv viden. Jeg forstår denne politiske repræsentant således, at politikkens primære funktion i Gentekniknævnet består i at omsætte den objektive kundskab til det som er politisk muligt. Al den stund den viden som politikken betjener sig af ses som objektiv, findes der heller ikke nogen grund for denne repræsentant til at se relationerne mellem politikerne og de forskellige sagkyndige som hjemsted for en dybere rationalitets- eller vidensproblematik.

En noget anden opfattelse finder vi hos den sidste af de politikere jeg skal lade komme til orde her. Denne politiker ser relationen mellem nævnets politikere, sagkyndige, etikere og jurister som grundlæggende præget af samarbejde. Som eksempel herpå nævnes de to interne heldagsseminarer som Gentekniknævnet har afholdt for at skabe en mulighed for fælles etisk refleksion blandt nævnets medlemmer. For denne repræsentant er det helt afgørende at nævnets medlemmer får en sådan mulighed for at «tænke højt» sammen. Det er noget som betaler sig, når man sidenhen vender tilbage til den konkrete sagsbehandling (Interview, politiker I, okt. 2003). Imidlertid er denne politiker ikke blind for at der kan findes visse spændinger i nævnet: 
Det finns ju ett antal (politiske repræsentanter i nævnet, TA) som i stort sett säger nej till allting... det kan jag också göra men jag vill ha argument för det. Men samtidig så måste det ju också finnas en broms i ett sådant här organ som gör att man tänker efter och har väl grundade argument [...] (Interview, politiker I, okt. 2003)

Den konflikt som omtales her, retter sig mod de politiske repræsentanter fra de partier som er skeptiske over for genteknikken. Denne repræsentant mener at deres skepsis ikke altid bygger på gode argumenter, men snarere på ideologiske rygmarvsreaktioner. Hertil kan man bemærke at det altid er forbundet med visse vanskeligheder at afgøre hvad der i en given situation er et godt argument. Udtalelsen i citatet oven for bunder imidlertid også i et andet problem, nemlig i problemet omkring nævnets beredskab for at tage politisk-etiske grundlagsspørgsmål op til diskussion. Når man om en begrundelse kan sige at den ikke bygger på «andet end ideologi» skyldes det at ideologi i mange tilfælde undsiger sig en procedure hvori gyldigheden af de udsagn som ideologien anvendes til at fremsætte, prøves med henblik på at skabe en kollektiv handling. Fraværet af grundlagsdiskussioner kan således skabe et underskud af begrundelse. De ideologiske tolkningsskemaer har, sådan opleves det, uafhængigt af eventuelle argumenter og problematiseringer, allerede leveret både problemformuleringen og problemløsningerne

\section{Videnskab}

En af Gentekniknævnets naturvidenskabeligt sagkyndige peger på at eventuelle uoverensstemmelser blandt de naturvidenskabeligt sagkyndige påvirker muligheden for at opnå enighed betydeligt mere end vedkommende havde forestillet sig, da han indtrådte i nævnet:

$[\ldots]$ om forskarna är eniga [...] och föra fram vetenskapliga sakskäl för att något inte skulle vara farligt eller tveksamt så får det en väldigt stark genomslagskraft...så vad jag försöker att säga tror jag är att den starkaste parten är i alla fall inte politikerna, vilket jag trodde när jag kom in i nämnden [...] (Interview, sagkyndig I, okt. 2003)

Ifølge denne sagkyndige er det nævnets juridiske ekspertise som har det sidste ord: «Men de juridiska sakkunniga, om det nu finns en hierarki, de är i princip oemotsagda, alltid [...]» (Interview, sagkyndig I, okt. 2003). Der hvor der viser sig en konfliktlinie, ifølge denne sagkyndige, er i de tilfælde hvor de politiske repræsentanter reserverer sig mod en beslutning eller udtalelse i nævnet. Det opfattes af dette nævnsmedlem som dybt beklageligt. Men der findes samtidig en forståelse for at de politiske repræsentanter ikke kan gå ud over visse partimæssige og ideologiske grænser for, hvorledes man bør se på genteknikkens forskellige anvendelsesområder. Bortset fra disse situationer opfattes nævnets arbejde som præget af stor enighed. 
Dette er noget som ifølge denne sagkyndige adskiller det nuværende nævn fra det som var udnævnt i perioden inden. I det foregående nævn blev afstemning ofte anvendt $i$ konkrete sager, noget som ikke forekommer i det nuværende nævn.

Samme grundopfattelse præger også en anden naturvidenskabelig sagkyndig i nævnet, som slår fast at de forskellige disciplinære og vidensmæssige tilhørsforhold som nævnets medlemmer repræsenterer, ikke på nogen måde afstedkommer konflikter. Tværtimod understreges det at diskussionerne som føres ved nævnets møder, kan ses som en lærerproces for alle i nævnet. Den mangfoldighed af synspunkter som kommer frem i nævnets diskussioner er vigtig:

[...] när det gäller slutmålet att få en vettig användning av [gen]tekniken och på konsumentens villkor [...] även om vi har en ordföranden där som är jurist, så kanske dom synpunkterna...dom finns med i bakgrunden de syns kanske inte så mycket $i$ diskussionen, det blir mycket av det etiska men inte av regler och så. Jag tycker det är en bra balans, framförallt att få sitta med politiker och förstå deras sätt att se det [...] (Interview, sagkyndig V, okt. 2003)

Denne beskrivelse peger for det første på at mangfoldigheden af synspunkter er vigtig for en acceptabel og forbrugerorienteret udvikling og anvendelse af GMO. For det andet udpeges de juridiske argumenter mere som en slags resonansbund, end som et perspektiv der manifesterer sig tydligt i nævnets diskussioner. Det er karakteristisk for denne sagkyndige at det er det etiske perspektiv som udpeges som det mest dominerende i Gentekniknævnets diskussioner. Det virker som om de naturvidenskabelige argumenters status ikke udgør noget selvstændigt problem for denne sagkyndige. Den altoverskyggende problematik for denne repræsentant i nævnet drejer sig om den etiske bearbejdning af den grundlæggende naturvidenskabelige analyse. Den naturvidenskabelige analyse og viden betragtes således som en konstant hvorom etiske og politiske vurderinger kredser.

En tilsvarende opfattelse af at der i nævnet grundlæggende findes en gensidig interesse $i$ at lære af hinanden, udtrykkes hos yderligere en sagkyndig repræsentant i Gentekniknævnet. Denne gensidighed må dog først overkomme en afgørende forhindring ifølge denne sagkyndige: «Man pratar olika språk [...] men vi lär från varandra så jag tycker det är bra att man har olika åsikter» (Interview, sagkyndig VI, okt. 2003).

Som et eksempel på hvorledes de forskellige «sprog» er blevet forsøgt tilnærmet, nævnes det interne seminar om etiske spørgsmål som Gentekniknævnet har afholdt for sine medlemmer. Formålet med seminariet (som nu er blevet en fast tradition) var at skabe en fælles forståelse for de etiske spørgsmål som opstår i forbindelse med introduktion af nye bioteknologiske teknikker i landbruget og i fødevareproduktionen. Men behovet for at nærme sig hinanden går ikke bare fra etik til videnskab, men også den 
anden vej (Interview, sagkyndig VI, okt. 2003). Derfor har Gentekniknævnet indført jævnlige studiebesøg til forskellige forskningsinstitutioner for at «uddanne» de ikke-naturvidenskabelige medlemmer og politikerne i nævnet. Ved at tilvejebringe en dybere viden om de videnskabelige problemstillinger og metoder som genteknikken arbejder med, håber man på at opnå en højere grad af gensidig forståelse omkring de normer som er nødvendige for at regulere området.

Det billede som træder frem når man ser nærmere på hvorledes de naturvidenskabelige sagkyndige ser på deres egen og andres kundskab, er præget af en opfattelse af at der råder konsensus i Gentekniknævnet. Denne for de sagkyndige så efterstræbelsesværdige tilstand trues dog i de tilfælde hvor konsensusbestræbelserne mislykkes og de politiske repræsentanter reserverer sig. På den ene side er der altså tale om en harmonisk og gensidig læreproces i Gentekniknævnet, men, som vi så, også en vis undren i forhold til den politiske rationalitet som danner klangbunden i nævnet.

\section{Etik}

Gentekniknævnets instruktion slår fast at der skal udpeges en etisk sagkyndig til Gentekniknævnet. I dag har Gentekniknævnet imidlertid både en etisk sagkyndig og en sagkyndig på det kulturvidenskabelige område. I flere af mine interviews fremgår det at Gentekniknævnets medlemmer ikke ser den store forskel på om den etiske og samfundsmæssige analyse er gjort af etikeren eller af den samfundsvidenskabelige repræsentant. Imidlertid findes der medlemmer i Gentekniknævnet som mener, at forskellen på den etiske analyse og den samfunds- og kulturvidenskabelige analyse ligger $i$ at den samfundsvidenskabelige analyse bringer offentlighedens holdninger til den nye genteknik ind i nævnets arbejde på en særlig måde. Imidlertid er det ikke så overraskende hvis mange af Gentekniknævnets medlemmer ikke umiddelbart ser den store forskel mellem den etiske og den kultur- og samfundsvidenskabelige analyse. I en konkret diskussion vil disse to perspektiver i mange tilfælde glide ind i hinanden og blive til en samlet analyse af hvad der i moralsk forstand bør gøres og hvad der findes kulturelt og samfundsmæssigt beredskab til at gøre. Mange af de etiske diskussioner som føres omkring genteknikken, tematiseres ofte i termer som handler om hvorledes genteknikkens etiske problematik dybest set handler om den måde hvorpå traderede normer og forståelsesformer forandres under trykket fra genteknikken; altså netop påvirkning på et kulturelt niveau. Den etiske diskussion i forbindelse med genteknikken drejer sig derfor ofte om at forstå konsekvenserne af denne teknologiske påvirkning af vores måder at skabe mening og sammenhæng på. Ser man på etikerens rolle i Gentekniknævnet, så fremkommer det at rollen som etisk sagkyndig aktualiserer 
en problematik med hensyn til hvad man som etiker egentlig repræsenterer i nævnet:

Även som etiker, där kan jag tycka att det är lite problematisk ibland, vad står jag för? Står jag för min egen övertygelse eller står jag för någon slags allmän etisk oro som finns kring detta? (Interview, sagkyndig III, okt. 2003)

Der peges her på problemet med at adskille den egne holdning til en vis anvendelse af genteknik, fra en mere upersonlig og generel analyse af hvilke etiske analysemodeller eller moralfilosofiska begreber, som kan anvendes for at synliggøre den etiske problematik i en given situation. I den forbindelse siges det:

Låt mig nämna ett exempel där jag har känt att det har blivit rätt jobbigt för mig, och det är alltså det här med märkning av gentekniska varor där jag personligen är övertygad om att det inte är ett dugg farligare att äta sådan här mat än någon annan mat och inte heller tycker jag att sådana här odlingssystem på något sätt skulle vara farligare...jag känner ingen oro inför detta, jag känner mig tvärtom fullständigt övertygad om att vi kommer att ha...sådana produkter och det kommer att fungera alldeles utmärkt. Men samtidig skall jag då som etisk sakkunnig...naturligtvis är det min plikt att stå upp för någon slags konsument perspektiv och försöka förstå alla dom här människorna som också är oroliga inför den här utvecklingen $[. .$.$] och då är det$ frågan, vem skall jag luta mig mot? Vems representant är jag i det läget? För mig personligen är detta ett [...] dilemma [...] (Interview, sagkyndig III, okt. 2003)

Det specifikt etiske relateres her til et forbrugerperspektiv som potentielt står i modsætning til både den personlige og den videnskabelige holdning. Følelsen af at befinde sig i et dilemma bliver selvfølgelig ikke mindre af at netop det etiske perspektiv, eller forbrugerperspektivet, ifølge denne sagkyndige, har en meget fremtrædende position i Gentekniknævnet. Det siges i denne forbindelse, at:

Många av de här politiska besluten som fattas och även de besluten vi fattar i Gentekniknämnden sker faktisk utifrån något slags socialt politisk konsumentorienterad perspektiv... än utifrån ett naturvetenskapligt perspektiv. Hela Gentekniknämnden som konstruktion är ett uttryck för detta (Interview, sagkyndig III, okt. 2003)

Hvad den etisk sagkyndige henviser til her er, som jeg allerede har været inde på, at de politiske og øvrige ikke-naturvidenskabelige repræsentanter i nævnet har til opgave at sikre at de beslutninger som tages, forholder sig til genteknikkens sociale dimensioner, herunder forbrugernes holdninger til f.eks. mad som indeholder GMO. Men det betyder selvfølgelig ikke at naturvidenskaben spiller en underordnet rolle. Tværtimod understreger denne sagkyndige at:

[...] i någon mening har naturvetenskapen en mycket stark position i våra diskussioner och det är klart att den utbildning vi får, för vi får en avsevärd utbildning i den 
här nämnden, den har i mycket hög grad en naturvetenskaplig karaktär [...] Men våra beslut motiveras inte alltid av naturvetenskapliga hänsyn, långt därifrån (Interview, sagkyndig III, okt. 2003)

Hvorledes skal man forstå relationen mellem etiske, sociale hensyn på den ene side og de naturvidenskabelige argumenters fremtrædende position på den anden? Vi vinder næppe nogen større indsigt om Gentekniknævnet ved at analysere relationen mellem sociale, etiske og naturvidenskabelige argumenter i nævnets arbejde som en ligevægtsrelation. Tværtimod vil jeg foreslå en tolkning hvor udtalelsen i citatet ovenfor ses som et udtryk for at der råder en vis orden mellem de etiske/sociale og de naturvidenskabelige argumenter. Det betyder at visse vidensformer mobiliseres i forskellige faser af en diskussions- og beslutningsproces i Gentekniknævnet. Naturvidenskaben anvendes tilsyneladende som grund eller udgangspunkt i diskussionerne, og den dominerende kollektive vidensproduktion ser da også ud til at være den naturvidenskabelige. Det betyder med andre ord at selve problemformuleringen og diskussionens genstand defineres naturvidenskabeligt. Men når man når frem til beslutnings- og motivationsfasen kan andre typer af argumenter og viden tage over, som f.eks. den etiske og/eller den sociale. Af dette kan man forledes til at tro at alle former for viden tildeles en given rolle i de drøftelser som finder sted i nævnet. Imidlertid problematiseres dette billede til en vis grad af den kulturvidenskabelige ekspert i nævnet:

\footnotetext{
Sen är det ju så att det kulturvetenskapliga får jag fightas för [...] det är ju så att, och det är inte bara i de här sammanhangen [...] det blir ju etik som blir det vanliga ickenaturvetenskapliga, icke-politiska perspektivet och då menar jag det är etik ur ett normativt synsätt där man vill komma åt: är det här nu bra eller är det dåligt, kan vi säga ja eller nej till det här? medan det inte finns någon beredskap att fundera i vardagliga kulturella perspektiv: vad tycker nu folk om detta, vad betyder det, vilka konsekvenser får det verkligen? Interview, sagkyndig IV, okt. 2003)
}

Det der indikeres her, er at der eksisterer en orden mellem de forskellige videnskulturer i nævnet. En rimelig tolkning er at det naturvidenskabelige perspektiv, sammen med det politiske perspektiv, hver især besidder en egen selvfølgelig legitimitet. Dertil kommer den normative etik som har erobret en position som et legitimt korrektiv i forhold til den naturvidenskabelige og politiske tolkning af den bioteknologiske problematik. Det kulturelle perspektiv derimod findes der endnu ikke noget beredskap for at tage ind i nævnets drøftelser. Paradoksalt nok møder netop det kulturelle perspektiv en betydelig interesse fra de politisk repræsentanters side i Gentekniknævnet. Dette forhold udtrykker den sagkyndige således:

[...] komplexitet och ambivalens frågorna vill jag hela tiden föra in som ett ytterligare perspektiv...och då blir egentligen alltid politikerna väldigt intresserade för då 
blir de intresserade av hur de skall kunna uppfattas av och bemötas av och själva bemöta allmänheten [...] politikerna vet att de måste ta folks rädslor eller förhoppningar på allvar (Interview, sagkyndig IV, okt. 2003)

I forlængelse af denne udtalelse siges det at man kan se politikerne som en slag bro mellem det kulturvidenskabelige og det naturvidenskabelige perspektiv. Det som fremkommer her, er således at der findes en kompleksitet i den kulturvidenskabelige analyse vedrørende genteknik som mødes af en vis skepsis fra naturvidenskabeligt hold, men som på den anden side opleves som yderst vigtig af de politiske repræsentanter. Men da de politiske repræsentanter samtidig er meget påpasselige med at tilgodese det naturvidenskabelige perspektiv, kommer politikerne i realiteten til at fremstå som brobyggere mellem de politiske, etiske og naturvidenskabelige aspekter på bekostning af de kulturvidenskabelige. Der kan næppe råde nogen tvivl om at politikernes interesse for det kulturvidenskabelige perspektiv delvis kan forklares med at politikerne i dette perspektiv kan finde forklaringsmodeller for at forstå menneskers holdninger og synspunkter i forhold til genteknikken. Dette hilses naturligvis velkommen fra politisk side idet offentligheden til stadighed forbløffer politikerne ved stædigt at fastholde en modstand mod f.eks. genmodificerede fødevarer. En modstand som af mange politikere nok ses som en politisk realitet, men samtidig dog som en uforklarlig sådan.

Jeg skal forlade de etiske og kulturvidenskabeligt sagkyndige her, for at i stedet vende mig mod den sidste gruppe, nemlig den juridiske sagkundskab i Gentekniknævnet.

Jura

En af nævnets jurister definerer Gentekniknævnets rolle på følgende måde:

Det har ju inte kommit upp att vi skall skapa visioner för framtiden [...] inte att peka fram mot hur det borde bli utan vi försöker se hur det möjligen kan bli [...] vi propagerar inte för gentekniken vi försöker bidra till en saklig diskussion (Interview, ledelse I, okt. 2003)

I denne formulering ser vi en ganske tydelig indikering af at nævnets rolle set fra et juridisk perspektiv er at give en objektiv og saglig fremstilling uden at blande normative holdninger til genteknikkens fremtid ind i billedet. Netop tilstedeværelsen af stærke normative og ideologiske holdninger udpeges som et problem når samme jurist om forholdet mellem politikerne og de naturvidenskabelige eksperter siger:

[...] däremot så har det ju stundom varit ganska starka motsättningar mellan å ena sidan naturvetarna och vissa politiker och dom har ju haft sin grund i att medan politikerna har haft en bestämd uppfattning om vad som bör ske och inte bör ske på 
det här området så har naturvetarna, säkert också haft en ganska bestämd uppfattning... Vetenskapsmännen har så att säga haft svårt att svälja... politiker överhuvudtaget som har [åsikter, TA] grundade inte på fakta utan på ett tyckande (Interview, ledelse I, okt. 2003)

Her skimter vi en konflikt som ikke tidligere har været så tydlig hverken i interviewerne med politikerne eller de sagkyndige på det naturvidenskabelige område. Som vi skal se i næste afsnit kan det meget vel være diskussionerne om hvorledes nævnet skal forholde sig til antibiotikaresistens, der implicit refereres til her.

En anden jurist i Gentekniknævnet peger på at det nuværende nævn er meget harmonisk i modsætning til det tidligere nævn. De spændninger som fandtes, er forsvundet siges det (Interview, ledelse II, okt. 2003). Samtidig understreges det at hvis man ser på konkrete sager som f.eks. spørgsmålet om antibiotikaresistens, så er nævnet ikke enigt. Her findes der et politisk mindretal som lægger forsigtighedsprincippet til grund for at reservere sig mod udsætning af genmodificerede planter som kan indeholde antibiotikaresistente markørgener. I denne sammenhæng kan det være interessant at notere, at dette medlem eksplicit peger på, ikke bare det ønskværdige $\mathrm{i}$ at have en juridisk kompetence i nævnet, men at dette er nødvendigt fordi:

[...] det är mycket juridik i samband med GMO hantering det är ingen tvekan om det, och ännu mera sen vi blev medlemmar i Europaunionen [...] det är då dels så kallade EU förordningar [...] dom gäller i och med att dom är antagna i Bryssel, så har vi också rätt viktiga direktiv som ju inte gäller i princip förrän dom har blivit, genom svensk lagstiftning, inordnat i den svenska rättsordningen (Interview, ledelse II, okt. 2003)

Den specifikt juridiske kundskab er således vigtig for at kunne foretage en kvalificeret vurdering af hvad der kan lade sig gøre, og hvad som ikke er muligt inden for det europæiske regelværk som vokser frem på det genteknologiske område. En sådan vurdering handler om, at kunne tolke både de nye lovgivningers materielle indhold og intension, samt at kunne forholde denne tolkning til Gentekniknævnets instruktion. Man kan forstå dette medlem således at den juridiske tolkningsproces skal vejlede Gentekniknævnet i hvor grænserne går for nævnets stillingtagen og ageren $\mathrm{i}$ forskellige konkrete tilfælde. På et mere principielt niveau handler dette medlems analyse af den juridiske kompetence om at kunne manøvrere i en stadig mere kompleks retslig virkelighed, præget af retslig internationalisering og en transformation af det traditionelle retsrealistiske paradigme til fordel for en retslig regulering, som i stigende grad beskrives som decentreret og refleksiv (Sand 1996; Boe 1993). Omend dette nævnsmedlem anvender andre begreber og kategorier, er der dog ingen tvivel om at det fænomen 
som beskrives har at gøre med en transformation af den dominerende retsrealistiske tradition. Dette kommer til udtryk således:

[...] etiken är ju numera tydligt invävd i juridiken eftersom miljöbalken är så väldigt tydlig när den lyfter fram dom etiska frågorna, och att det här att all miljöpolitik och överhuvudtaget hela samhällsorganisationen skall syfta till: hållbar utveckling och naturen värd att bevara. [...] och därför står dom inledande paragraferna som vi tidigare...den typen av portalparagrafer var det enligt vår rättstradition ingen som brydde sig så mycket om [...] Men numera genom inflytande av Europeisk rättstradition så är man mera observant på det, för nu har dom här inledande paragraferrna som är väldigt tydliga just i miljöbalken t.ex. lite av samma karaktär som preambeln har t.ex. i direktiv eller i en EG förordning där de talar om syftet, talar om målsättningar och lite om avvägningar som skall göras (Interview, ledelse II, okt. 2003)

Hvad visse medlemmer opfatter som en tilbagetrukket kontrolfunktion er for juristerne selv en rolle hvor de dels skal opretholde den normative distinktion mellem er og bør, og dels gøre det muligt for nævnet at agere i relation til den nye juridiske virkelighed som er ved at vokse frem i Sverige qua den svenske retstraditions interaktion med en mere kontinental retstradition (Achen1997: 296-300).

Normproduktionen i Gentekniknævnet er, som vi har set, bundet op på en forhandling og positionering mellem forskellige traditioner og videnssystemer. Det er klart at i denne situation er der ikke ingen normer eller principper som passerer uimodsagt. Tværtimod må vi forstå tilstedeværelse af disse vidensdomæner: politik, videnskab, etik, jura som den systemiske ramme som bestemmer tolkningerne af de normer og principper som bringes ind i de forhandlinger som foregår i Gentekniknævnet. En anden måde at udforske den forhandlede normdannelse i Gentekniknævnet på er ved at se på hvorledes nævnet har ageret konkret under nogle turbulente år i slutningen af 1990'erne. Det skal jeg gøre i det næste afsnit.

\section{Kommercialisering af bioteknikken og normproduktion $\mathrm{i}$ Gentekniknævnet}

Læser man Gentekniknævnets årsberetning for året 1995-1996, hvori man også informerer regeringen og Riksdagen om de aktuelle udviklingstendenser på genteknikområdet, så finder man en tør konstatering af at man har godkendt import fra USA af herbicidtolerant soya (Verksamhetsredogörelse 1995-96). Men derimod finder vi i årsredegørelsen for 1997 en formulering om at introduktionen af soyaprodukter i EU fra USA har ledt til omfattende debat i Sverige (Verksamhetsredogörelse 1997). Spørgsmålet er hvilke konkrete spor introduktionen af disse produkter satte i nævnets normproduktion? 
På Gentekniknævnets møde den 24 januar 1996 behandles som punkt 10 på dagsordenen et notat fra Jordbruksverket (Protokol 960 124, bilag 7). I skrivelsen redegører Jordbruksverket for den svenske holdning når det gælder markedsgodkendelse af herbicidtolerant raps. Jordbruksverket siger her at man er fortaler for en «restrictive attitude», så længe de langsigtede effekter af herbicidtolerance ikke er bedre evalueret end de er. Denne position støttes af Gentekniknævnet. Det er intressant at notere at Jordbruksverket allerede tidligt i 1996 begyndte at formulere en policy i forhold til herbicidtoleranse. Denne policy skulle der blive god brug for sidenhen. At man befinder sig i en kvalitativt ny fase allerede inden årene 1996 og 1997 kommer også til udtryk i Gentekniknævnets redegørelse for udviklingen af genteknikken i 1995 hvor man konstaterer at kommercialiseringen nu er en realitet (Protokol 960 221, punkt 5, bilag 3).

Gentekniknævnet står således over for en helt ny situation hvor det ikke længere handler om at vurdering af forskningens fremtidige gevinster eller trusler, men om faktiske produkter på markedet. Det er værd at bemærke i denne sammenhæng at Gentekniknævnet allerede på dette tidspunkt er opmærksom på den kommende mærkningsproblematik som skulle kunne opstå i forbindelse med introduktionen af disse nye genmodificerede produkter. Man beslutter derfor på februarmødet 1996 at indlede en diskussion om mærkning af fødevarer (Protokol 960 221). Imidlertid vender spørgsmålet tilbage i en mere konfliktbetonet variant på samme møde i februar 1996 da man skal behandle dagsordenens punkt 7, der har følgende ordlyd: «Yttrande över remis från Jordbruksverket angående förslag till EU-kommissionens beslut rörande utsläppande på marknaden av genetisk modifierade sojabönor» (Protokol 960 221, punkt 7).

Gentekniknævnets stillingtagen i denne sag er, set i bakspejlet, ikke helt ukontroversiel. Man tilslutter sig fra nævnets side EU-kommissionens opfattelse om at det ikke er nødvendigt at det på en vares etiket skal angives at det aktuelle produkt er fremstillet ved hjælp af genteknik. Denne opfattelse bunder i den udbredte holdning i Gentekniknævnet at det ikke er teknikken i sig selv som er problematisk, men derimod visse af teknikkens applikationer. Når man i dag ser tilbage på dette forløb, kan man konstatere at denne opfattelse ikke har vundet indpas i EU:s nye GMO-direktiv 2001/ $18 \mathrm{Om}$ udseetning i miljøet af genetisk modificerede organismer, hvori mærkning med ovennævnte ordlyd netop er blevet et krav. Af mødereferatet fremgår det at tre af de parlamentariske medlemmer i Gentekniknævnet reserverede sig mod denne beslutning (Protokol 960 221, bilag 5). I erkendelse af at man her har at gøre med et spørgsmål der involverer en række modstridende interesser, beslutter man på mødet at holde en høring i forbindelse med Gentekniknævnets møde den 17 april 1996 om mærkning af genteknisk modificerede fødevarer. Endvidere beslutter man at holde et seminar om samme spørgsmål i Riksdagshuset den 8 maj 1996 (Protokol 
960 221, punkt 10). På nævnets møde den 20 marts1996 kommer spørgsmålet om forbrugeroplysning op igen, idet Jordbruksverket udbeder sig Gentekniknævnets stillingstagen til to ansøgninger om makedsintroduktion af genetisk forandret majs og salat, fra henholdsvis Frankrig og Holland. Gentekniknævnet stiller sig i begge tilfælde bag en sådan godkendelse, men påpeger i sit svar vigtigheden af en alsidig forbrugeroplysning om produkternes egenskaber (Protokol 960 320, punkt 5, bilag 3).

Spørgsmålet om genmodificerede fødevarer får i slutningen af 1996 konkrete konsekvenser for Gentekniknævnet. Den vigtigste og mest kontroversielle konsekvens er den diskussion som indledes med Naturvårdsverket i December 1996. På mødet den 11. december behandler man en skrivelse fra Naturvårdsverket med titlen 'Policy om främmande organismer och gener' (Protokol 961 211, punkt 6, bilag 3). Under diskussionen i nævnet fremkommer en kritik af formuleringen «fremmede organismer och gener» som stående i modsætning til «naturliga gener». Det er bemærkelsesværdigt at Gentekniknævnets kritik i denne sammenhæng til en vis grad retter sig mod Naturvårdsverkets brug af forsigtighedsprincippet. Man påpeger fra nævnets side at hvis forsigtighedsprincippet indebærer at man skal kunne bevise at et vist indgreb i naturen er absolut risikofrit, så kan man ikke stille sig bag en sådan tolkning af forsigtighedsprincippet. Dette kan undre al den stund at hverken Naturvårdsverket eller andre centrale aktører på miljøområdet har været fortaler for en sådan tolkning. Gentekniknævnets markering må derfor ses som et udtryk for en generel uro for hvor forsigtighedsprincippets bevisgrænse skal trækkes. Det er hovedsageligt de naturvidenskabeligt sagkyndige som står for denne uro. Dette ses bl.a. ved at to af Gentekniknævnets sagkyndige føler sig kaldet til at afgive en egen kritisk mindretalsudtalelse i anledning af Naturvårdsverkets skrivelse.

Imidlertid er det ikke helt uproblematisk for Gentekniknævnet at være i opposition til Naturvårdsverket, idet Naturvårdsverket har det overordnede policy- og samordningsansvar på miljøområdet i Sverige. Hvis der foreligger en væsentlig forskel mellem Gentekniknævnet og Naturvårdsverket med hensyn til tolkningen af de risici som er forbundet med introduktionen af genforændrede planter og organismer i det svenske miljø, og i forbindelse hermed en uenighed om tolkningen af forsigtighedsprincippet, så er det i Gentekniknævnets interesse at forsøge at rede trådene ud. Det er netop hvad der sker når man på Gentekniknævnets møde i december 1996 beslutter at sende en opfordring til Naturvårdsverket om at afholde et fælles møde i februar måned 1997. I referatet fra Gentekniknævnets møde den 29. januar 1997 ser vi at man behandler et brev til Naturvårdsverket hvori nævnet anmoder Naturvårdsverket om at lade sig repræsentere på højeste ledelsesniveau (Protokol 970 129, punkt 2). Afrapporteringen af mødet med Naturvårdsverket skete på Gentekniknævnets efterfølgende møde den 
26. februar 1997. Af referatet fremgår det, at man blev enig med Naturvårdsverket om at man skulle nedsætte en fælles arbejdsgruppe som skulle fortsætte diskussionen om introduktion og spredning af fremmede organismer og gener i miljøet.

At hele spørgsmålet om herbicidresistens er et kontroversielt politisk spørgsmål vidner en anden sag man havde oppe på mødet i februar 1997 om. Jordbruksverket havde tilsendt Gentekniknævnet en forespørgelse om at ytre sig vedrørende en ansøgning fra den belgiske virksomhed Plant Genetic Systems vedrørende en introduktion af en genforandret majs på markedet. Nævnets sagkyndige anbefalede at man skulle bifalde ansøgningen idet markørgenerne for antibiotikaresistens i dette tilfælde var elimineret. Man så således ingen risiko for genflow eller eventuelle allergiske reaktioner hos forbrugerne. Men 5 af de 7 politikere i nævnet reserverer sig med den begrundelse at der stadig eksisterer en usikkerhed når det drejer sig om hvorledes man skal vurdere risikoen forbundet med markedsintroduktionen af herbicidresistente produkter. Dette er et illustrativt eksempel på hvorledes eksperterne og politikerne vurderer samme sag forskelligt. De facto handler det om at disse to grupper i Gentekniknævnet anvender sig af forsigtighedsprincippet på to forskellige måder. Forskerne ser princippet som en videnskabelig garant for at der ikke tillades introduktion af planter eller produkter som beviseligt indebærer en økologisk eller sundhedsmæssig risiko. Politikerne derimod anvender forsigtighedsprincippet som et instrument for at kunne navigere i forhold til en folkelig opinion som på dette tidspunkt er stærkt skeptisk mod introduktionen af genforandrede planter i landbruget, og følgelig også mod tilstedeværelsen af genmodifierede organismer i fødevarer (Protokol 970 226, punkt 6). Som en afspejling af den ophedede debat, som fandt sted i begyndelsen af 1997, kan man se forslaget fra et af Gentekniknævnets medlemmer om at nævnet bør skride ind over for virksomheden Karlshamn AB, fordi denne virksomhed ikke har kunnet bevise om, og i givet fald i hvilken udstrækning, dets produkter kan indeholde genforandrede planteprodukter (Protokol 970 226, punkt 12).

Diskussionerne, om hvorledes man skal se på herbicidresistens fortsætter i løbet af 1997 med at dele Gentekniknævnet. Ansøgningerne strømmer ind og stadig flere ansøgninger venter på godkendelse. Det mærkes tydeligt at kommercialiseringen af genteknikken på landbrugs- og fødevareområdet tager fart. Således mødes nævnet på sit møde den 16. april 1997 af en ansøgning om at foretage feltforsøg med genforandrede sukkerroer. Endnu en gang ser vi det nu etablerede mønster gentage sig: eksperterne støtter ansøgningen, mens politikerne modsætter sig forslaget med henvisning til den usikkerhed der findes med hensyn til herbicidresistente afgrøder (Protokol 970 416, punkt 2, bilag 1). Fra flere sider i nævnet begynder man på dette tidspunkt at opfatte den konsekvente fodnotepolitik som en del af de poli- 
tiske repræsentanter i Gentekniknævnet fører, som irriterende da den bryder med den konsensustradition som flertalet i Gentekniknævnet ønsker at videreføre.

Denne konsensusambition giver sig udtryk i at man begynder at diskutere en standardformulering som Gentekniknævnet skulle kunne afgive når det drejer sig om herbicidresistens og antibiotikaresistens, som på tilfredsstillende vis skulle kunne opfange minoritetens vurderinger i disse sager (Protokol 970 514, punkt 5, bilag 1). Ikke at man derved opnår en enighed, men man kan undgår at mindretalsudtalelserne optager for meget tid og at de grundlæggende forskelle i bedømmelserne diskuteres på ny hver gang en ny ansøgning kommer op på Gentekniknævnets dagsorden. Man kan således sige at det er en løsning som betinges af at man lukker en diskussion i erkendelse af at positionerne er så låste at ingen nye synspunkter eller indsigter kan genereres. Der ligger selvfølgelig en fare i at automatisere holdningstilkendegivelsen på denne måde. Når man alligevel vælger at gøre det, tror jeg man med stor sikkerhed kan sige, at det skete ud fra en effektivitetsvurdering. Hen over foråret og sommeren 1997 diskuteres det hvorledes en sådan standardformulering skulle kunne se ud. På Gentekniknævnets møde i september samme år anvendes disse præfabrikerede mindretalsudtalelser for første gang i forbindelse med en forespørgelse fra Jordbruksverket om udsætning af genforandret rasp i dyrkningssæsonen 1997/98 (Protokol 970 917, punkt 10, bilag 3). Man kan imidlertid ikke sige at der falder ro over Gentekniknævnet som følge af dette tiltag. På mødet i Gentekniknævnet den 10. december 1997 behandler man nemlig den første svenske ansøgning indsendt til svenske myndigheder (Jordbruksverket) om godkendelse af kommerciel dyrkning af en genetisk forandret kartoffel. At den folkelige uro og debat ikke er forstummet her mod slutningen af 1997 ses bl.a. ved at samtlige politikere i Gentekniknævnet modsætter sig denne godkendelse. Gentekniknævnets eksperter bifalder ifølge det kendte mønster ansøgningen (Protokol 971 210, punkt 3, bilag 4).

Som vi har set, har spørgsmålet om herbicidtolerans og antibiotikaresistens været et kontroversielt spørgsmål i Gentekniknævnet under årene 1996 og 1997. Imidlertid har Gentekniknævnet, når det drejer sig om antibiotikaresistente markørgener, formuleret en policy som afviser anvendelsen af sådanne markørgener i afgrøder når der findes teknisk mulighed for at fjerne disse resistente markørgener. Startskuddet til denne policy kom på mødet i Gentekniknævnet den 25. marts 1998, hvor en af de politiske repræsentanter formulerede en usædvanlig skarp modstand mod at Gentekniknævnet på trods af sin principielle modstand mod antibiotikaresistente markørgener alligevel tillader forsøgsdyrkning af afgrøder med sådanne gener. Denne inkonsekvens, som i reservationen kaldes for både ulogisk og uetisk, møder forståelse i nævnet (Protokol 980 325, punkt 2, bilag 3). På samme møde præsenterer man en udtalelse til Kemikaliein- 
spektionen, i forbindelse med at inspektionen udarbejder et oversigtsdokument vedrørende antibiotikaresistente markører i genmodificerede organismer. Gentekniknævnet skriver i sin policy:

Däremot är risken för horisontal genöverföring av antibiotikaresistensgener från genmodifierade mikroorganismer till den naturliga bakterieflora betydligt större, varför sådan inte ska accepteras för utsättning i naturen eller utsläppande på marknaden (Protokol 980 325, punkt 11, bilag 10)

Selvom man her taler om mikroorganismer og ikke om GMO generelt er det vigtige dog at man tilslutter sig det principielle argument om det uforsvarlige $i$ at anvende antibiotikaresistente markørgener. I november samme år holder Gentekniknævnet en høring om dette emne. Det baggrundsdokument som udarbejdedes i denne forbindelse, spiller en væsentlig rolle for den restriktive policy som Gentekniknævnet har i dag. På mødet den 18. februar 1999 afviser man derfor en ansøgning fra Agro Evo A/S om at gennemføre et feltforsøg med sukkerroer som bl.a. er resistente mod Kanamycin. Gentekniknævnet afviser ansøgningen med begrundelsen at der nu findes tekniske muligheder for at undgå at denne resistens overføres til planter som plantes ud på friland, og at denne teknik ikke er anvendt i dette tilfælde. Imidlertid reserverer en af de juridiske eksperter sig med henvisning til at det kun er et år siden at Gentekniknævnet begyndte at udtrykke indvendinger mod denne type af resistens, og at der derfor findes retssikkerhedshensyn som taler for at man bifalder ansøgningen (Protokol 990 218, punkt 4).

På Gentekniknævnets møde den 24. marts 1999 behandles et brev fra Jordbruksverket (Skrivelse fra jordbruksverket Dnr. 226 899/98) hvor man giver udtryk for at man på Jordbruksverket $i k k e$ forstår de etiske grunde som Gentekniknævnet angiver for ikke at kunne bifalde visse typer af udsætning af genmodificerede planter (Protokol 990 324, punkt 4, bilag 9). Man ønsker fra Jordbruksverkets side at Gentekniknævnet tydeliggører sine etiske standpunkter i de sager som har været til behandling i nævnet. De sager der refereres til, er dem hvor Gentekniknævnet har afslået en ansøgning med henvisning til nævnets modstand mod brugen af antibiotikaresistente markørgener, i afgrøder hvor det er teknisk muligt at undgå overførsel til det samlede plantemateriale. Med henblik på at formulere et svar tages sagen atter op på nævnets møde den 2. juni 1999. På mødet fremlægges et udkast til et svar hvori det hedder: «[...] det kan därför ses som en etisk fråga i vilken mån hänsynen till allmänhetens reaktioner skall väga över strikt vetenskapliga riskbedömmningar» (Protokol 990 602, punkt 5, bilag 7). Gentekniknævnet siger endvidere at man vil tage sin policy på dette område op til fornyet overvejelse på nævnets næste møde. Således arbejder man på mødet den 16. juni 1999 videre med dette spørgsmål om en policy, og på mødet den 3. november 1999 kan man vedtage en ny revi- 
deret policy om antibiotikaresistens (Protokol 990 616, punkt 3; Protokol 991 103, punkt 3, bilag 5).

Hvis vi vender tilbage til citatet ovenfor, er der to forhold der er bemærkelsesværdige. For det første, at relationen mellem offentlighedens syn på anvendelsen af antibiotikaresistente markørgener kontrasteres mod den videnskabelige risikobedømmelse. Det impliceres her at den videnskabelige risikobedømmelse principielt kan gå i den diametralt modsatte retning af offentlighedens opfattelse af antobiotikaresistens. Hvilken vægt offentlighedens og videnskabens syn på sagen skal have defineres dernæst som et etisk spørgsmål. For det andet er det bemærkelsesværdigt at der implicit i denne etiske problemformulering ligger en erkendelse af at Gentekniknævnet er villig til $i$ en vis udstrækning at lade de videnskabelige argumenter vige, for dermed at imødegå offentlighedens skepsis mod anvendelse af genteknik i fødevareproduktionen. Det svar som Gentekniknævnet afgiver til Jordbruksverket i denne konkrete sag, implicerer at Jordbruksverket bør forstå at Gentekniknævnet restriktive attitude i forhold til antibiotikaresistens, ikke alene bygger på videnskabelige argumenter, men også inddrager en bredere politisk-etisk bedømmelse af hvorledes den moderne genteknik som anvendes i fødevareproduktion, bør håndteres med henblik på at opnå en accept $\mathrm{i}$ offentligheden. For at dette argument skal få virkningskraft i forhold til Jordbruksverket, defineres selve grundproblemet: Det normativa skisma mellem offentlighedens natur- og miljøsyn og den videnskabelige risikobedømmelse som et etisk problem. I kraft af denne problemformuleringsmanøvre kan Gentekniknævnet formidle en kritik af Jordbruksverkets holdning til antibiotikaresistens, for ikke at være tilstrækkelig sensitiv overfor de bioteknologiske og bioetiske problemer som ligger til grund for offentlighedens skepsis i relation til f.eks. antibiotikaresistens.

Normerne i svensk biopolitik formuleres som vi så ovenfor bl.a. ud fra en tolkning af hvorledes forbrugernes interesser bedst varetages, hvad der er politisk opportunt, den tekniske udvikling og nævnets relation til andre myndigheder. Det vil sige at den forhandlede normdannelse både styres af de normer og normkonflikter som genereres internt i nævnet, samtidig med at disse normer filtreres gennem en række videnskabelige, politiske, sociale og institutionelle problestillinger som nævnet konfronteres med. Skal man forstå denne proces som et eksempel på anvendt etik, så bliver svaret at Gentekniknævnet ikke anvender etik for at løse en konflikt eller et dilemma. I langt højere grad er der tale om at Gentekniknævnet iscenesætter og selv agerer i et netværk af aktører som forhandler de normer som skal gælde for den svenske biopolitik. Det normative resultat af disse processer er flygtigt og skifter i samme takt som aktører forlader netværket eller nye inkluderes. Flygtigheden i det normative resultat kommer dessuden af at disse aktørers tolkning af sig selv og deres omverden forandres afhængigt af 
den 'læsning' de gør hver især af den sociale, økonomiske, politiske samt teknisk-videnskabelige situation i hvilken de befinder sig.

\section{Anvendt etik og forhandlet normdannelse: en afsluttende kommentar}

I denne artikel har jeg argumenteret for at den traditionelle anvendte etik bør suppleres med en procedural diskursetik for at kunne teoretisere og forstå den forhandlede normdannelse. At tale om forhandlet normdannelse indebærer ikke en afvisning af eksistensen af substantielle etiske normer. Begrebet om den forhandlede normdannelse fokuserer imidlertid på de betingelser som råder for at disse normer kan opnå samfundsmæssig gyldighed. Politisk peger diskussionen om den forhandlede normdannelse på en bredere undersøgelse om deliberativt demokrati som en forudsætning for at tilvejebringe de nødvendige samfundsmæssige anerkendelses- og inklusionsmekanismer som i sidste instans er en forudsætning for normativ konsensus. For at forstår hvorledes den forhandlede normdannelse konkret foregår er det nødvendigt at studere normerende institutioners funktionsmåde og indre liv. Studiet af Gentekniknævnet tjener netop dette formål. Når man går tæt på institutioner som Gentekniknævnet opdager man at de forandrede samfundsmæssige betingelser som tesen om en forhandlede normdannelse bygger på, udmyntes konkret i den måde hvorpå normproduktionen foregår i Gentekniknævnet. Det blir også tydeligt at spørgsmålet om hvorvidt en aktør som Gentekniknævnet er en relevant normerende institution, ikke er afgjort en gang for alle, men netop indgår i den radikaliserede begrundelses- og gyldighedstvang som Gentekniknævnet og andre lignende institutioner er underlagt. Normativ relevans kommer således ikke af sig selv qua den formelle forvaltningsretslige ret til at udøve myndighed. Tværtimod, Gentekniknævnets normative og styringsmæssige relevans produceres i og med nævnets italesættelse af de teknologiske, etiske, politiske og sociale problemstillinger som gør sig gældende når det drejer sig om anvendelsen af genteknik i fødevareproduktionen. Det forhold at normdannelsen sker som en forhandling, sætter Gentekniknævnets styringsmæssige muligheder på spil, og aktualiserer spørgsmålet om Gentekniknævnets evne til at identificere, udvikle og vedligholde nævnets etiske formuleringskompetence. Spørgsmålet er nu om Gentekniknævnet, og andre lignende institutioner, er sig disse udfordringer bevidst? 


\section{Litteratur}

Achen, T. (1997) Den bioetiske udfordring. Linköping: Linköping Studies in Arts and Science.

Achen, T. (2005) Nedslag i svensk biopolitik. Linköping: Tema T rapport 43.

Boe, E. (1993) Forvaltningsrettslige polycentritendenser. In Retlig polycentri, eds. Peter Blume og Hanne Petersen. p. 283-305. København: Akademisk Forlag.

Habermas, J. (1990) Moral Consciousness and Communicative Action. Cambridge, Massachusetts: MIT Press.

Kettner, M. (1993) Scientific Knowledge, Discourse Ethics, and Consensus Formation in the Public Domain. In Applied Ethics: A Reader, eds. E. R. Winkler og J. R. Coombs, p. 28-45. Oxford: Blackwell.

Luhmann, N. (1992) Hvorfor «systemteori»? In Autopoiesis, ed. Jens Christian Jacobson, p. 10-20. København: Politisk Revy.

Pedersen, Ove. K., Niels Å. Andersen, Peter Kjær og John Elberg (1992) Privat politik. Københavns: Samfundslitteratur.

Sand, I.-J. (1996) Styring av kompleksitet. Oslo: Fagbokforlaget.

Schanz, H-J. (1988) Tendenser - omkring pragmatik, kunst og modernitet. Aarhus: Modtryk.

Schomberg, R. von. (2007) From the Ethics of Technology towards an Ethics of Knowledge Policy \& Knowledge Assessment. Brussels: European Commission, Directorate-General for Research, Science, Economy and Society.

Stehr, N. (2003) Wissenspolitik: Die Überwachung des Wissens. Frankfurt: Suhrkamp.

Sverige, Förordning 1994:902 med instruktion för Gentekniknämnden.

Sverige, Gentekniknämnden. Protokoll 960 124, ärende 10, bilaga 7.

Sverige, Gentekniknämnden. Protokoll 960 221, bilaga 5.

Sverige, Gentekniknämnden. Protokoll 960 221, ärende 10.

Sverige, Gentekniknämnden. Protokoll 960 221, ärende 5, bilaga 3.

Sverige, Gentekniknämnden. Protokoll 960 221, ärende 7.

Sverige, Gentekniknämnden. Protokoll 960 320, ärende 5, bilaga 3.

Sverige, Gentekniknämnden. Protokoll 961 211, ärende 6, bilaga 3.

Sverige, Gentekniknämnden. Protokoll 970 129, ärende 2.

Sverige, Gentekniknämnden. Protokoll 970 226, ärende 12.

Sverige, Gentekniknämnden. Protokoll 970 226, ärende 6.

Sverige, Gentekniknämnden. Protokoll 970 416, ärende 2, bilaga 1.

Sverige, Gentekniknämnden. Protokoll 970 514, ärende 5, bilaga 1.

Sverige, Gentekniknämnden. Protokoll 970 917, ärende 10, bilaga 3.

Sverige, Gentekniknämnden. Protokoll 971 210, ärende 3, bilaga 4.

Sverige, Gentekniknämnden. Protokoll 980 325, ärende 11, bilaga 10.

Sverige, Gentekniknämnden. Protokoll 980 325, ärende 2, bilaga 3.

Sverige, Gentekniknämnden. Protokoll 990 218, ärende 6.

Sverige, Gentekniknämnden. Protokoll 990 324, ärende 4, bilaga 9.

Sverige, Gentekniknämnden. Protokoll 990 602, ärende 5, bilaga 7.

Sverige, Gentekniknämnden. Protokoll 990 616, ärende 3.

Sverige, Gentekniknämnden. Protokoll 991 103, ärende 3, bilaga 5.

Sverige, Gentekniknämnden. Verksamhetsredogörelse för budgetåret 1995-1996.

Sverige, Gentekniknämnden. Verksamhetsredogörelse för budgetåret 1997.

Sverige, Jordbruksverket DNR 226 899/98 datered 990318. 
Winkler, E. R. (1993) From Kantianism to Contextualism: The Rise and Fall of the Paradigm Theory in Bioethics. In Applied Ethics: A Reader, eds. E. R. Winkler og J. R. Coombs, p. 344-365. Oxford: Blackwell.

\section{Noter}

1 Jeg vil gerne takke de to anonyme læsere samt redaktionen for konstruktive kommentarer på en tidligere version af artiklen. Denne artikel indgår i COMPASS-projektet som ledes af Margareta Bertilsson og financieres af NOS-S. Tak til Gentekniknævnet som stillede sit arkiv til rådighed. Sidst men ikke mindst en tak til Helle Rydstrøm for kommentarer undervejs.

2 Det var J.-F. Lyotards bog La condition postmoderne fra 1979 (på dansk 1982) som satte diskussionen igang.

3 Schomberg (2007). Rapporten udtrykker ikke kommissionens officielle synspunkt men den peger på udfordringer som kommissionen anser at EU står overfor.

4 Förordning 1994:902 med instruktion för Gentekniknämnden. 